\title{
Akibat Hukum Putusan Pra Peradilan Terhadap Penetapan \\ Tersangka Dugaan Melakukan Tindak Pidana Korupsi \\ Di Sekretariat DPRD Tulang Bawang (Studi Putusan Nomor: 6/Pid.Pra/2020/PN.Tjk)
}

\section{Legal Consequences of Pre-Trial Decisions on Determination of Suspects Alleged with Corruption Crime At the DPRD Tulang Bawang Secretariat (Decision Study Number: 6/Pid.Pra/2020/PN.Tjk)}

\author{
Ismi Rahmawati, \\ Program Studi Ilmu Hukum Fakultas Hukum Universitas Bandar Lampung \\ (Ismi.17211098@student.ubl.ac.id)
}

Bambang Hartono, Program Studi Ilmu Hukum Fakultas Hukum Universitas Bandar Lampung (Bambang.hartono@ubl.ac.id)

\section{Zainudin Hasan}

Program Studi Ilmu Hukum Fakultas Hukum Universitas Bandar Lampung (Zainudin.Hasan@student.ubl.ac.id)

Abstrak: $\quad$ Salah satu perkara pengajuan pra peradilan terhadap penetapan tersangka dugaan melakukan tindak pidana korupsi adalah Putusan Nomor: 6/Pid.Pra/2020/PN.Tjk, dimana pada putusan tersebut menyatakan bahwa berdasarkan pertimbanganpertimbangan tersebut diatas, Hakim berkesimpulan bahwa tindakan tindakan Termohon yang menetapkan Pemohon sebagai Tersangka karena adanya penyimpangan pengeluaran anggaran Sekretariat DPRD Kabupaten Tulang Bawang Tahun Anggaran 2018-2019 telah sesuai peraturan perundang undangan, sehingga Surat Penetapan Tersangka Nomor S.Tap/03/VI/2020 Ditreskrimsus tertanggal 23 Juni 2020 terhadap Pemohon adalah sah dan mempunyai kekuatan hukum mengikat. Memperhatikan Pasal 77 Undang-undang Nomor 8 Tahun 1981 tentang Hukum Acara Pidana, Putusan Mahkamah Konstitusi Nomor 21/PUUXII/2014 tertanggal 28 April 2015 dan Peraturan Mahkamah Agung 
RI Nomor 4 Tahun 2016 serta peraturan perundang-undangan lain yang bersangkutan serta Menolak permohonan praperadilan Pemohon untuk seluruhnya .Permasalahan penelitian ini adalah: Bagaimana proses penyidikan tindak pidana korupsi Sekretariat DPRD Tulang Bawang oleh Polda Lampung, Apakah dasar pertimbangan hakim Pengadilan Negeri Tanjung Karang dalam putusan Nomor: 6/Pid.Pra/2020/PN.Tjk yang menolak permohonan pra peradilan tersangka? dan Apa akibat hukum dari Putusan Pra peradilan Nomor: 6/Pid.Pra/2020/PN.Tjk. Metode penelitian menggunakan pendekatan yuridis normatif dan empiris. Jenis data yang digunakan adalah data sekunder dan data primer. Pengumpulan data melalui penelitian kepustakaan (library research) dan penelitian lapangan (field research). Analisis data yang digunakan adalah yuridis kualitatif.

Kata Kunci: Akibat Hukum; Pra Peradilan; Korupsi.

Abstract: $\quad$ One of the pre-trial filing cases against the determination of the suspect of allegedly committing a criminal act of corruption was Decision Number: 6 / Pid.Pra / 2020 / PN.Tjk, where the decision stated that based on the above considerations, the Judge concluded that the Respondent's actions who determined the Petitioner as a suspect due to irregularities in spending the budget of the Bone Bawang Regency DPRD Secretariat for the 2018-2019 Fiscal Year has been in accordance with the laws and regulations, so that the Suspect Determination Letter Number S. Tap / 03 / VI / 2020 / Ditreskrimsus dated 23 June 2020 against the Petitioner is valid and has binding legal force. Taking into account Article 77 of Law Number 8 of 1981 concerning Criminal Procedure Law, Constitutional Court Decision Number 21 / PUUXII / 2014 dated April 28, 2015 and Regulation of the Supreme Court of the Republic of Indonesia Number 4 of 2016 as well as other relevant laws and regulations and rejecting the petition The Petitioners' pretrial for all. The problem of this research is: How is the process of investigating the criminal act of corruption at the Bone Bawang DPRD Secretariat by the Lampung Regional Police? and What are the legal consequences of the Pre-trial Decision Number: 6 / Pid.Pra / 2020 / PN.Tjk. The research method used normative and empirical juridical approaches. The type of data used is secondary data and primary data. Collecting data through library research and field research. The data analysis used was qualitative juridical.

Keywords: Legal Consequences, Pre Trial, Corruption 


\section{PENDAHULUAN}

Pra peradilan bukan merupakan lembaga peradilan tersendiri, bukan pula sebagai instansi tingkat peradilan yang memiliki wewenang memberikan putusan akhir atas suatu peristiwa pidana. ${ }^{1}$

Pra peradilan adalah lembaga peradilan yang menjadi wewenang mengadili bagi Pengadilan Negeri untuk menilai sah atau tidaknya penahanan, penyitaan, penghentian penyidikan, atau penghentian penuntutan yang dilakukan oleh penyidik atau penuntut umum, Wewenang hakim pra peradilan sesuai KUHAP adalah hanya sebatas memutuskan mengenai sah atau tidaknya penangkapan, penahanan, pengehentian penyidikan, penghentian penuntutan, termasuk ganti kerugian atau rehabilitasi bagi seseorang yang perkaranya telah dihentikan.

Hakikat mengajukan upaya pra peradilan adalah untuk menegakkan hukum dan melindungi hak asasi tersangka dalam tingkat penyidikan dan penuntutan. Potensi penyalahgunaan wewenang bisa terjadi pada tingkat penyidikan dan penuntutan oleh aparat penegak hukum terhadap seseorang misalnya mengurangi dan membatasi hak kemerdekaan dan hak asasi tersangka yang seharusnya menurut hukum tidak boleh dilakukan kepada seseorang yang diduga sebagai pelaku ataupun tersangka. Tujuan pra peradilan untuk mempertanggungjawabkan tindakan aparat penegak hukum yang arogan, melampaui kewenangannya, tidak sesuai prosedur, bertentangan dengan Hak Asasi Manusia dan bertentangan dengan hukum.

Pra peradilan merupakan wewenang Pengadilan Negeri untuk memeriksa dan memutus tentang sah atau tidaknya suatu penangkapan dan/atau penahanan atau permintaan tersangka atau keluarganya atau pihak lain atau kuasa tersangka; sah atau tidaknya penghentian penyidikan atau penghentian penuntutan atas permintaan demi tegaknya hukum dan keadilan; serta permintaan ganti kerugian atau rehabilitasi oleh tersangka atau keluarganya atau pihak lain atau kuasanya yang perkaranya tidak diajukan ke pengadilan. Pra peradilan merupakan salah satu lembaga hukum baru yang diciptakan dalam Kitab Undang-Undang Hukum Acara Perdata (KUHAP). Secara tidak langsung, Pra peradilan melakukan pengawasan atas kegiatan yang dilakukan penyidik dalam rangka penyidikan maupun penuntutan, mengingat tindakan penyidik pada dasarnya melekat pada instansi yang bersangkuatan dengan adanya pengawasan antara Kepolisian dan Kejaksaan sebagai penyidik dalam hal penghentian penyidikan dan penuntutan.

Pada sistem Peradilan Pidana yang berlaku di Indonesia, Pra peradilan sebagai lembaga yang lahir bersamaan dengan diberlakukannya

\footnotetext{
1 Nur Hidayat. 2010. Penghentian Penyidikan Oleh Penyidik Polri dan Upaya Hukumnya. Jurnal Yustitia. Vol.10. No.1, hlm. 22 .
} 
Undang-Undang Nomor 8 Tahun 1981 tentang Hukum Acara Pidana yang selanjutnya disebut (KUHAP) serta menjadi acuan Hukum Acara Pidana yang tidak lain untuk menjamin penegakan hukum dan Hak Asasi Manusia yang telah digariskan baik dalam landasan konstitusional maupun dalam Undangundang Nomor 39 Tahun 1999 tentang Hak Asasi Manusia.

Berkaitan dengana dan jaminan terhadap HAM, dapat diartikan bahwa dalam setiap konstitusi selalu ditemukana danya jaminan terhadap HAM. Dalam Undang-Undang Dasar 1945 melalui beberapa pasal yang mengatur tentang HAM, salah satunya adalah Pasal 27 ayat (1) yang berbunyi: "Segala warga negara bersamaan kedudukannya di dalam hukum dan pemerintahan dan wajib menjunjung hukum dan pemerintahan itu dengan tidak ada kecualinya". Pasal 27 ayat (1) ini di implementasikan dalam proses peradilan pidana sebagai Azas Praduga Tak Bersalah yang diatur dalam Pasal 8 Undang-Undang Nomor 48 Tahun 2009 tentang Kekuasaan Kehakiman Republik Indonesia.

Tujuan dari azas ini adalah untuk memberi batasan seseorang, baik tersangka atau terdakwa dari tindakan yang sewenang-wenang yang dilakukan oleh aparat penegak hukum dalam menjalankan tugasnya. Tindakan sewenang-wenang ini berupa upaya paksa dari penegak hukum yang dalam hal ini memungkinkan melanggar HAM tersangka atau terdakwa, dilakukan dengan kekerasan (violence) dan penyiksaan (torture). Maka dalam peradilan dibentuk lembaga baru yang diperkenalkan Kitab Undang-Undang Hukum Acara Pidana (KUHAP) di tengah-tengah kehidupan penegakan hukum yang bernama Pra peradilan yang berfungsi untuk mengontrol tindakan aparat penegak hukum agar tidak melampaui kewenangannya.

Lembaga pra peradilan sejak semula dimasukkan sebagai sarana hukum yang dapat digunakan untuk mengajukan tuntutan oleh tersangka, korban, penyidik, penuntut umum maupun pihak ketiga yang berkepentingan terhadap pelaksanaan kewenangan penegak hukum. Dengan adanya lembaga pra peradilan ini, maka setiap tindakan sewenang-wenang terhadap hak asasi manusia yang dilakukan oleh penegak hukum dalam melakukan upaya paksa dapat dikontrol. Namun dalam perjalanannya, lembaga pra peradilan tidak mampu menjawab permasalahan yang ada dalam proses pra-ajudikasi, karena fungsi pengawasan pranata pra peradilan hanya bersifat post facto dan pengujiannya hanya bersifat formal yang mengedepankan unsur objektif, sedangkan unsur subjektifnya tidak dapat diawasi pengadilan.

Pengajuan pra peradilan yang seharusnya memiliki arti penting dalam rangka penegakan hukum, melindungi pihak-pihak (tersangka, keluarga atau kuasanya) yang menjadi korban ketidaksewenangwenangnya aparat penegak hukum baik dalam proses penyelidikan, penyidikan hingga penetapan sebagai tersangka. Namun seringkali hakim pra peradilan melakukan kekeliruan nyata, dimana judul perkaranya pra 
peradilan akan tetapi substansinya telah memasuki pokok perkara,karena materi pokok perkara bukan dalam jangkauan lembaga pra peradilan yang semestinya menjadi pertimbangan hukum dan putusannya bersifat pembuktian administratif.

Fungsi utama dari pra peradilan dapat dioptimalkan, bahwa pra peradilan harus dilakukan secara cepat dan tepat mendahului proses pokok perkara dalam rangka memulihkan harkat/martabat Tersangka, namun juga dengan mempertimbangkan bahwa kajian ini menitikberatkan pada penambahan objek pra peradilan yaitu penetapan status Tersangka, yang lebih spesifiknya dalam kasus Tindak Pidana Korupsi. Alhasil fungsi check and balances yang sesungguhnya akan dapat terlaksana sepenuhnya, ketika kajian karya tulis ilmiah ini terakomodasi di dalam peraturan perundang-undangan.

\section{METODE}

Metode penelitian menggunakan pendekatan yuridis normatif dan empiris. Jenis data yang digunakan adalah data sekunder dan data primer. Pengumpulan data melalui penelitian kepustakaan (library research) dan penelitian lapangan (field research). Analisis data yang digunakan adalah yuridis kualitatif.

\section{HASIL DAN PEMBAHASAN}

Pra peradilan bukan merupakan lembaga peradilan tersendiri, bukan pula sebagai instansi tingkat peradilan yang memiliki wewenang memberikan putusan akhir atas suatu peristiwa pidana. ${ }^{2}$

Pra peradilan adalah lembaga peradilan yang menjadi wewenang mengadili bagi Pengadilan Negeri untuk menilai sah atau tidaknya penahanan, penyitaan, penghentian penyidikan, atau penghentian penuntutan yang dilakukan oleh penyidik atau penuntut umum, Wewenang hakim pra peradilan sesuai KUHAP adalah hanya sebatas memutuskan mengenai sah atau tidaknya penangkapan, penahanan, pengehentian penyidikan, penghentian penuntutan, termasuk ganti kerugian atau rehabilitasi bagi seseorang yang perkaranya telah dihentikan.

Hakikat mengajukan upaya pra peradilan adalah untuk menegakkan hukum dan melindungi hak asasi tersangka dalam tingkat penyidikan dan

\footnotetext{
2 Nur Hidayat. 2010. Penghentian Penyidikan Oleh Penyidik Polri dan Upaya Hukumnya. Jurnal Yustitia. Vol.10. No.1, hlm. 22 .
} 
penuntutan. Potensi penyalahgunaan wewenang bisa terjadi pada tingkat penyidikan dan penuntutan oleh aparat penegak hukum terhadap seseorang misalnya mengurangi dan membatasi hak kemerdekaan dan hak asasi tersangka yang seharusnya menurut hukum tidak boleh dilakukan kepada seseorang yang diduga sebagai pelaku ataupun tersangka. Tujuan pra peradilan untuk mempertanggungjawabkan tindakan aparat penegak hukum yang arogan, melampaui kewenangannya, tidak sesuai prosedur, bertentangan dengan Hak Asasi Manusia dan bertentangan dengan hukum.

Pra peradilan merupakan wewenang Pengadilan Negeri untuk memeriksa dan memutus tentang sah atau tidaknya suatu penangkapan dan/atau penahanan atau permintaan tersangka atau keluarganya atau pihak lain atau kuasa tersangka; sah atau tidaknya penghentian penyidikan atau penghentian penuntutan atas permintaan demi tegaknya hukum dan keadilan; serta permintaan ganti kerugian atau rehabilitasi oleh tersangka atau keluarganya atau pihak lain atau kuasanya yang perkaranya tidak diajukan ke pengadilan. Pra peradilan merupakan salah satu lembaga hukum baru yang diciptakan dalam Kitab Undang-Undang Hukum Acara Perdata (KUHAP). Secara tidak langsung, Pra peradilan melakukan pengawasan atas kegiatan yang dilakukan penyidik dalam rangka penyidikan maupun penuntutan, mengingat tindakan penyidik pada dasarnya melekat pada instansi yang bersangkuatan dengan adanya pengawasan antara Kepolisian dan Kejaksaan sebagai penyidik dalam hal penghentian penyidikan dan penuntutan.

Pada sistem Peradilan Pidana yang berlaku di Indonesia, Pra peradilan sebagai lembaga yang lahir bersamaan dengan diberlakukannya UndangUndang Nomor 8 Tahun 1981 tentang Hukum Acara Pidana yang selanjutnya disebut (KUHAP) serta menjadi acuan Hukum Acara Pidana yang tidak lain untuk menjamin penegakan hukum dan Hak Asasi Manusia yang telah digariskan baik dalam landasan konstitusional maupun dalam Undangundang Nomor 39 Tahun 1999 tentang Hak Asasi Manusia.

Berkaitan dengana dan jaminan terhadap HAM, dapat diartikan bahwa dalam setiap konstitusi selalu ditemukana danya jaminan terhadap HAM. Dalam Undang-Undang Dasar 1945 melalui beberapa pasal yang mengatur tentang HAM, salah satunya adalah Pasal 27 ayat (1) yang berbunyi: "Segala warga negara bersamaan kedudukannya di dalam hukum dan pemerintahan dan wajib menjunjung hukum dan pemerintahan itu dengan tidak ada kecualinya". Pasal 27 ayat (1) ini di implementasikan dalam proses peradilan pidana sebagai Azas Praduga Tak Bersalah yang diatur dalam Pasal 8 Undang-Undang Nomor 48 Tahun 2009 tentang Kekuasaan Kehakiman Republik Indonesia. 
Tujuan dari azas ini adalah untuk memberi batasan seseorang, baik tersangka atau terdakwa dari tindakan yang sewenang-wenang yang dilakukan oleh aparat penegak hukum dalam menjalankan tugasnya. Tindakan sewenang-wenang ini berupa upaya paksa dari penegak hukum yang dalam hal ini memungkinkan melanggar HAM tersangka atau terdakwa, dilakukan dengan kekerasan (violence) dan penyiksaan (torture). Maka dalam peradilan dibentuk lembaga baru yang diperkenalkan Kitab Undang-Undang Hukum Acara Pidana (KUHAP) di tengah-tengah kehidupan penegakan hukum yang bernama Pra peradilan yang berfungsi untuk mengontrol tindakan aparat penegak hukum agar tidak melampaui kewenangannya.

Lembaga pra peradilan sejak semula dimasukkan sebagai sarana hukum yang dapat digunakan untuk mengajukan tuntutan oleh tersangka, korban, penyidik, penuntut umum maupun pihak ketiga yang berkepentingan terhadap pelaksanaan kewenangan penegak hukum. Dengan adanya lembaga pra peradilan ini, maka setiap tindakan sewenang-wenang terhadap hak asasi manusia yang dilakukan oleh penegak hukum dalam melakukan upaya paksa dapat dikontrol. Namun dalam perjalanannya, lembaga pra peradilan tidak mampu menjawab permasalahan yang ada dalam proses pra-ajudikasi, karena fungsi pengawasan pranata pra peradilan hanya bersifat post facto dan pengujiannya hanya bersifat formal yang mengedepankan unsur objektif, sedangkan unsur subjektifnya tidak dapat diawasi pengadilan.

Pengajuan pra peradilan yang seharusnya memiliki arti penting dalam rangka penegakan hukum, melindungi pihak-pihak (tersangka, keluarga atau kuasanya) yang menjadi korban ketidaksewenang-wenangnya aparat penegak hukum baik dalam proses penyelidikan, penyidikan hingga penetapan sebagai tersangka. Namun seringkali hakim pra peradilan melakukan kekeliruan nyata, dimana judul perkaranya pra peradilan akan tetapi substansinya telah memasuki pokok perkara,karena materi pokok perkara bukan dalam jangkauan lembaga pra peradilan yang semestinya menjadi pertimbangan hukum dan putusannya bersifat pembuktian administratif.

Fungsi utama dari pra peradilan dapat dioptimalkan, bahwa pra peradilan harus dilakukan secara cepat dan tepat mendahului proses pokok perkara dalam rangka memulihkan harkat/martabat Tersangka, namun juga dengan mempertimbangkan bahwa kajian ini menitikberatkan pada penambahan objek pra peradilan yaitu penetapan status Tersangka, yang lebih spesifiknya dalam kasus Tindak Pidana Korupsi. Alhasil fungsi check and balances yang sesungguhnya akan dapat terlaksana sepenuhnya, 
ketika kajian karya tulis ilmiah ini terakomodasi di dalam peraturan perundang-undangan.

Pra peradilan adalah suatu tindakan yang dilakukan oleh Pengadilan Negeri untuk memeriksa dan memutus tentang keabsahan penangkapan, penahanan, penghentian penyidikan, penghentian penuntutan dan memutus permintaan ganti kerugian serta rehabilitasi yang perkara pidanannya tidak dilanjutkan ke muka sidang pengadilan negeri atas permintaan tersangka atau terdakwa atau pelapor atau keluarganya dan atau penasehat hukumnya. ${ }^{3}$

Pengertian Pra peradilan menurut Pasal 1 Angka 10 KUHP adalah wewenang Pengadilan Negeri untuk memeriksa dan memutus tentang: Sah atau tidaknya suatu penangkapan dan atau penahanan atau permintaan tersangka atau keluarganya atau pihak lain atau kuasa tersangka; Sah atau tidaknya penghentian penyidikan atau penghentian penuntutan atas permintaan demi tegaknya hukum dan keadilan; Permintaan ganti kerugian atau rehabilitasi oleh tersangka atau keluarganya atau pihak lain atau kuasanya yang perkaranya tidak diajukan ke pengadilan. Pra peradilan bukan lembaga peradilan yang mandiri atau berdiri sendiri terlepas dari pengadilan negeri, pra peradilan hanyalah wewenang tambahan Lembaga pra peradilan bukan badan tersendiri, tetapi hanya suatu wewenang saja dari pengadilan negeri. ${ }^{4}$

Pra peradilan dibentuk oleh KUHAP untuk menjamin perlindungan hak asasi manusia dan agar para aparat penegak hukum menjalankan tugasnya secara konsekwen. Dengan adanya lembaga pra peradilan, KUHAP telah menciptakan mekanisme kontrol yang berfungsi sebagai lembaga yang berwenang untuk melakukan pengawasan bagaimana aparat penegak hukum menjalankan tugas dalam peradilan pidana. ${ }^{5}$

Pra peradilan hanyalah wewenang tambahan yang diberikan kepada Pengadilan Negeri serta diberikan wewenang untuk memeriksa dan memutus permasalahan atau kasus yang terjadi dalam penggunaan wewenang upaya paksa yang dilakukan oleh Penyidik dan Penuntut Umum. Dalam perkara pra peradilan biasanya adadua pihak, yaitu pihak Pemohon dan pihak Termohon. Pihak pemohon adalah tersangka, keluarga maupun kuasa hukumnya. Sedangkan pihak termohonadalah penyidik atau

\footnotetext{
${ }^{3}$ Mochamad Anwar, 1989, Pra peradilan, Jakarta, Ind-Hil-Co, hlm. 25

${ }^{4}$ Ratna Nurul Afiah. 1986. Pra peradilan dan Ruang Lingkupnya. Akademika Pressindo. Jakarta, hlm.3.

${ }^{5}$ Moch. Faisal Salam,.2001. Hukum Acara Pidana Dalam Teori \& Praktek. Mandar Maju. Bandung, hlm. 124.
} 
jaksa penuntut umum. Pihak pemohon merasa ada aturan ataupun haknya merasa dirugikan oleh Penyidik maupun Jaksa Penuntut Umum, kemudian pemohon mengajukan hal ini ke lembaga pra peradilan dalam penyelesaian perkara pidananya yang merasa haknya dirugikan oleh termohon.

Pemberian wewenang ini bertujuan untuk menegakkan hukum dan keadilan secara sederhana, cepat dan murah dalam rangka memulihkan harkat/martabat, kemampuan/kedudukan serta mengganti kerugian terhadap korban yang merasa dirugikan. Lembaga pra peradilan juga merupakan lembaga baru yang tidak dijumpai dalam hukum acara pidana HIR.

Menurut Pasal 1 butir (10) KUHAP menyatakan Pra peradilan adalah wewenang Pengadilan Negeri untuk memeriksa dan memutus menurut cara yang diatur dalam Undang-Undang Nomor 8 Tahun 1981 tentang:

a. Sah atau tidaknya suatu penangkapan dan atau penahanan atas permintaan tersangka atau keluarganya atau pihak lain atas kuasa tersangka;

b. Sah atau tidaknya penghentian penyidikan atau penghentian penuntutan atas permintaan demi tegaknya hukum dan keadilan;

c. Permintaan ganti kerugian atau rehabilitasi oleh tersangka atau keluarganya atau pihak lain atas kuasanya yang perkaranya tidak diajukan ke pengadilan.

d. Pra peradilan tidak diatur di dalam ketentuan HIR (Herziene Inlands Reglement). ${ }^{6}$

Acara pra peradilan untuk ketiga hal, yaitu pemeriksaan sah tidaknya suatu penangkapan atau penahanan (Pasal 79 KUHAP), pemeriksaan sah tidaknya suatu penghentian penyidikan atau penuntutan (Pasal 80 KUHAP), pemeriksaan tentang ganti kerugian dan/atau rehabilitasi akibat tidak sahnya penangkapan atau penahanan atau akibat sahnya penghentian penyidikan (Pasal $81 \mathrm{KUHAP}$ ) ditentukan beberapa hal berikut:

a. Tiga hari setelah diterimanya permintaan, hakim yang ditunjuk menetapkan hari sidang;

b. Memeriksa dan memutus tentang sah tidaknya penangkapan atau penahanan atau tidaknya penghentian penyidikan atau penuntutan, permintaan ganti kerugian dan/atau rehabilitasi akibat tidak sahnya penangkapan atau penahanan, akibat sahnya penghentian penyidikan atau penuntutan dan ada benda yang disita yang tidak termasuk alat

\footnotetext{
${ }^{6}$ R. Soeparmono,2003. Pra peradilan dan Penggabungan Perkara Ganti Kerugian dalam KUHAP, Bandung, Mandar Maju , , hlm. 6
} 
pembuktian, hakim mendengar keterangan baik tersangka atau pemohon maupun dari pejabat yang berwenang;

c. Pemeriksaan tersebut dilakukan secara cepat dan selambat-lambatnya tujuh hari hakim harus sudah menjatuhkan putusannya;

d. Perkara yang sudah mulai diperiksa oleh Pengadilan Negeri, sedangkan pemeriksaan mengenai permintaan kepada pra peradilan belum selesai maka permintaan tersebut gugur;

e. Putusan pra peradilan pada tingkat penyidikan tidak menutup kemungkinan untuk mengadakan pemeriksaan pra peradilan lagi pada tingkat pemeriksaan oleh Penuntut Umum, jika untuk itu diajukan permintaan baru (semua yang tersebut pada butir 1 sampai dengan 5 ini diatur dalam Pasal 82 ayat (1) KUHAP);

f. Putusan hakim dalam acara pemeriksaan peradilan dalam ketiga hal tersebut harus memuat dengan jelas dasar dan alasannya (Pasal 82 ayat (2) KUHAP);

g. Selain daripada yang tersebut pada butir 6, putusan hakim ini memuat pula diantaranya:

1) Dalam hal putusan menetapkan bahwa sesuatu penangkapan atau penahanan tidak sah maka penyidik atau jaksa penuntut umum pada tingkat pemeriksaan masing-masing harus segera membebaskan tersangka;

2) Dalam hal putusan menetapkan bahwa sesuatu penghentian penyidikan atau penuntutan tidak sah, penyidikan atau penuntutan terhadap tersangka wajib dilanjutkan;

3) Dalam hal putusan menetapkan bahwa suatu penangkapan atau penahanan tidak sah maka dalam putusan dicantumkan rehabilitasinya;

4) Dalam hal putusan menetapkan bahwa benda yang disita ada yang tidak termasuk alat pembuktian maka dalam putusan dicantumkan bahwa benda tersebut harus segera dikembalikan kepada tersangka atau dari siapa benda itu disita.

Tujuan dari Lembaga Pra peradilan Setiap hal yang baru, tentunya mempunyai suatu maksud dan tujuan atau motivasitertentu. Pasti ada yang hendak dituju dan dicapai. Tidak ada sesuatu yang ingindiciptakan tanpa didorong oleh maksud dan tujuan. Demikian pula halnya dengan pelembagaan pra peradilan. Maksud dan tujuan yang hendak ditegakkan dandilindungi, yaitu:

a. Perlindungan hak-hak asasi manusia, terutama mereka yang terlibat dalam perkara pidana, khususnya pada tahap penyidikan dan penuntutan; 
b. Alat kontrol terhadap penyidik atau penuntut umum terhadap penyalahgunaan wewenang olehnya. ${ }^{7}$

Tindakan upaya paksa yang dikenakan instansi penegak hukum merupakanpengurangan dan pembatasan kemerdekaan dan hak asasi tersangka, tindakan ituharus dilakukan secara bertanggung jawab menurut ketentuan hukum dan Undang-Undangyang berlaku (due process of law). Prinsip yang terkandung padapra peradilan bermaksud dan tujuan guna melakukan tindakan pengawasanhorizontal untuk mencegah tindakan hukum upaya paksa yang berlawanan dengan Undang-Undang.

Wewenang Lembaga Pra peradilan berdasarkan dari segi struktur dan susunan peradilan, pra peradilan bukan lembaga pengadilan yang berdiri sendiri. Bukan pula sebagai instansi tingkat peradilan yang mempunyai wewenang dalam memberi putusan akhir atas suatu kasus peristiwapidana. Pra peradilan hanya suatu lembaga baru yang ciri dan eksistensinya sebagai berikut:

a. Berada dan merupakan kesatuan yang melekat pada Pengadilan Negeri dan sebagai lembaga pengadilan, hanya dijumpai pada tingkat Pengadilan Negeri sebagai satuan tugas yang tidak terpisah dari Pengadilan Negeri;

b. Pra peradilan bukan berada di luar atau di samping maupun sejajar dengan Pengadilan Negeri, tapi hanya merupakan divisi dari Pengadilan Negeri, administratif yustisial, personil, peralatan dan finansial bersatu dengan Pengadilan Negeri, dan berada di bawah pimpinan serta pengawasan dan pembinaan Ketua Pengadilan Negeri;

c. Tata laksana fungsi yustisialnya merupakan bagian dari fungsi yustisial Pengadilan Negeri itu sendiri. ${ }^{8}$

KUHAP tidak bertitik tolak pada orientasi kekuasaan. Fungsi wewenang dankekuasaan yang diberikan KUHAP kepada masing-masing jajaran aparat penegakhukum, diseimbangkan dengan pemberian hak yang sah dan legal kepada setiaptersangka atau terdakwa. Ini harus benar-benar diresapi oleh semua jajaran aparatpenegak hukum. Bahwa dominannya asas keseimbangan sebagai titik sentral dalam KUHAP merupakan keinginan dan tujuan pembuat undang-undang untukmembatasi penumpukan kekuasaan. ${ }^{9}$

Pengadilan melalui lembaga pra peradilan ikut memainkan peranan dalammembatasi kecenderungan penyalahgunaan dan kecongkakan

\footnotetext{
${ }^{7}$ M. Yahya Harahap. 2010. Pembahasan Permasalahan dan Penerapan KUHAP Pemeriksaan Sidang Pengadilan, Banding, Kasasi dan Peninjauan Kembali. Sinar Grafika. Jakarta, hlm. 3

${ }^{8} \mathrm{Ibid}, \mathrm{hlm} .4$.

${ }^{9}$ Ibid, hlm. 8.
} 
kekuasaan yangdilakukan aparat penyidik atau penuntut umum. Wewenang pertama yang telahdiberikan oleh KUHAP yang memeriksa dan memutus sah tidaknya suatupenangkapan atau penahanan yang dilakukan oleh penyidik. Dalam halpenangkapan, seseorang dapat mengajukan pemeriksaan kepada pra peradilantentang ketidakabsahan penangkapan yang dilakukan terhadap dirinya.M. Yahya Harahap menjelaskan kriteria suatu penangkapan dianggap tidak sah, yaitu:

a. Apabila dalam melakukan penangkapan, seorang penyidik tidak menyertakan surat tugas dan surat perintah penangkapan untuk diperlihatkan kepada tersangka, selain itu jika tembusan surat penangkapan tidak diberikan kepada pihak keluarganya;

b. Apabila batas waktu penangkapan lewat satu hari maka dapat dimintakan pemeriksaan kepada pra peradilan. ${ }^{10}$

Pasal 79 dan Pasal 80 KUHAP mengatur hal mengenai yang berwenang mengajukan pra peradilan, yaitu menjelaskan:

Pasal 79 KUHAP:

Permintaan pemeriksaan tentang sah atau tidaknya suatu penangkapan atau penahanan diajukan oleh tersangka, keluarganya atau kuasanya kepada ketua pengadilan negeri dengan menyebutkan alasannya.

Pasal 80 KUHAP:

Pemeriksaan untuk memeriksa sah atau tidaknya suatu penghentian penyidikan atau penuntutan dapat diajukan oleh penyidik atau penuntut umum atau pihak ketiga yang berkepentingan kepada ketua pengadilan negeri dengan menyebutkan alasannya.

Berdasarkan pasal-pasal tersebut dapat disimpulkan yang berhak mengajukan pra peradilan:

a. Tersangka, keluarga atau kuasa hukumnya;

b. Penyidik atau penuntut umum;

c. Pihak ketiga yang berkepentingan. ${ }^{11}$

Demi tegaknya the rule of law, maka siapapun yang bersalah harus dihukum. Demikian juga apabila penyidik ataupun penuntut umum salah dalam menjalankan tugas penyidikan ataupun penuntutan akan dapat dituntut oleh mereka yang dirugikan (baik tersangka maupun pihak ketiga) selama penyidikan ataupun penuntutan itu berlangsung. ${ }^{12}$

\footnotetext{
10 Ibid, hlm. 16.

11 Tri Andrisman, 2010, Hukum Acara Pidana, Unila Press. Bandar Lampung, hlm.48

${ }^{12}$ Anang Priyanto, 2012. Hukum Acara Pidana Indonesia. Ombak. Yogyakarta, hlm.55
} 
Adanya pra peradilan dijamin bahwa seseorang tidak ditangkap atau ditahan tanpa alasan yang sah. Penangkapan hanya dilakukan atas dasar dugaan yang kuat dengan landasan bukti permulaan yang cukup. Sedangkan ketentuan tentang bukti permulaan ini diserahkan penilaiannya kepada penyidik. Hal ini membuka kemungkinan sebagai alasan pengajuan pemeriksaan pra peradilan. ${ }^{13}$

Pra peradilan merupakan lembaga baru yang ciri eksistensinya:

1) Berada dan merupakan kesatuan yang melekat pada Pengadilan Negeri, dan sebagai lembaga pengadilan, hanya dijumpai pada tingkat Pengadilan Negeri sebagai satuan tugas yang tidak terpisah dari Pengadilan Negeri.

2) Pra peradilan bukan berada di luar atau di samping maupun sejajar dengan Pengadilan Negeri, tetapi hanya merupakan divisi dari Pengadilan Negeri.

3) Administratif yustisial, personil, peralatan, dan finansial bersatu dengan Pengadilan Negeri, dan berada di bawah pimpinan serta pengawasan dan pembinaan ketua pengadilan negeri

4) Tata laksana fungsi yustisialnya merupakan bagian dari fungsi yustisial pengadilan itu sendiri. ${ }^{14}$

Segala sesuatu yang menyangkut administrasi dan pelaksanaan tugas Pra peradilan, berada di bawah ruang lingkup kebijaksanaan dan tata laksana ketua pengadilan negeri. Semua permintaan yang diajukan kepada Pra peradilan, melalui Ketua Pengadilan Negeri. Sehubungan dengan hal tersebut, pengajuan permintaan pemeriksaan Pra peradilan, dapat diuraikan sebagai berikut:

1) Permohonan ditujukan kepada Ketua Pengadilan Negeri

2) Permohonan Diregister dalam Perkara Pra peradilan

3) Ketua Pengadilan Negeri Segera Menunjuk Hakim dan Panitera

4) Pemeriksaan dilakukan dengan Hakim Tunggal. ${ }^{15}$

Keberadaan lembaga pra peradilan bertujuan untuk memberikan perlindungan terhadap hak-hak asasi manusia yang sekaligus berfungsi sebagai sarana pengawasan secara horizontal, atau dengan kalimat yang lebih tegas dapat dikatakan bahwa diadakannya pra peradilan mempunyai maksud sebagai sarana pengawasan horizontal dengan tujuan memberikan perlindungan terhadap hak-hak asasi manusia terutama hak asasi tersangka dan terdakwa.

\footnotetext{
${ }^{13}$ Ibid, hlm.4.

${ }^{14} \mathrm{Ibid}, \mathrm{hlm} .5$.

${ }^{15}$ H.M.A Kuffal. 2008. Penerapan KUHAP dalam Praktik Hukum, UMM Press, Malang, hlm. 251.
} 
Dasar terwujudnya pra peradilan menurut Pedoman Pelaksanaan KUHAP adalah sebagai berikut: "Mengingat bahwa demi kepentingan pemeriksaan perkara diperlukan adanya pengurangan-pengurangan dari hak-hak asasi tersangka, namun bagaimanapun hendaknya selalu berdasarkan ketentuan yang diatur dalam undang-undang, maka untuk kepentingan pengawasan terhadap perlindungan hak- hak asasi tersangka/terdakwa diadakan lembaga yang dinamakan pra peradilan. ${ }^{16}$

Berdasarkan Undang-Undang Nomor 8 Tahun 1981 tentang Kitab UndangUndang Hukum Acara Pidana (Sebelum adanya Putusan MK Nomor 21/PUU- XII/2014), Pra peradilan sendiri berdasarkan Pasal 1 Angka 10, merupakan wewenang pengadilan negeri untuk memeriksa dan memutus tentang:

1) Sah atau tidaknya suatu penangkapan dan atau penahanan atas permintaan tersangka atau keluarganya atau pihak lain atas kuasa tersangka;

2) Sah atau tidaknya penghentian penyidikan atau penghentian penuntutan atas permintaan demi tegaknya hukum dan keadilan;

3) Permintaan ganti kerugian atau rehabilitasi oleh tersangka atau keluarganya atau pihak lain atas kuasanya yang perkaranya tidak diajukan ke pengadilan.

Tugas pra peradilan di Indonesia memang terbatas, dalam Pasal 78 yang berhubungan dengan Pasal 77 KUHAP dikatakan bahwa yang melaksanakan wewenang pengadilan negeri memeriksa dan memutus tentang berikut:

a. Sah tidaknya penangkapan, penahanan, penghentian penyidikan atau

penghentian penuntutan;

b. Ganti kerugian dan/atau rehabilitasi bagi seorang yang perkara pidananya dihentikan pada tingkat penyidikan atau penuntutan. ${ }^{17}$

Berdasarkan Putusan Mahkamah Konstitusi Nomor 21/PUU-XII/2014 yang diajukan oleh Pemohon yaitu Bachtiar Abdul Fatah dalam pengujian Pasal 77 huruf a KUHAP terhadap UUD 1945, putusan yang menyatakan penetapan tersangka merupakan objek pra peradilan sebagaimana diatur dalam Pasal 77 huruf a KUHAP. Dari putusan Mahkamah Konsitusi Nomor 21/PUU- XII/2014 yaitu menyatakan mengabulkan permohonan Pemohon untuk sebagian:

1) Pasal 77 huruf a Undang-Undang Nomor 8 Tahun 1981 tentang Hukum Acara Pidana (Lembaran Negara Republik Indonesia Tahun 1981,

\footnotetext{
${ }^{16}$ M. Yahya Harahap. 2008. Pembahasan Permasalahan dan Penerapan KUHAP (Pemeriksaan Sidang Pengadilan. Banding. Kasasi dan Peninjauan Kembali). Sinar Grafika. Jakarta, hlm. 49.

${ }^{17}$ Andi Hamzah. 2010. Hukum Acara Pidana Indonesia. Sinar Grafika. Jakarta, hlm. 189.
} 
Nomor 76, Tambahan Lembaran Negara Republik Indonesia Nomor 3209) bertentangan dengan Undang-Undang Dasar Negara Republik Indonesia Tahun 1945 sepanjang tidak dimaknai termasuk penetapan tersangka, penggeledahan, dan penyitaan.

2) Pasal 77 huruf a Undang-Undang Nomor 8 Tahun 1981 tentang Hukum Acara Pidana (Lembaran Negara Republik Indonesia Tahun 1981, Nomor 76, Tambahan Lembaran Negara Republik Indonesia Nomor 3209) tidak mempunyai kekuatan hukum mengikat sepanjang tidak dimaknai termasuk penetapan tersangka, penggeledahan, dan penyitaan.

Pra peradilan dipimpin oleh Hakim Tunggal yang ditunjuk oleh ketua pengadilan negeri dan dibantu oleh seorang Panitera. Dalam Pasal 79, Pasal 80 dan Pasal 81 diperinci tugas pra peradilan itu yang meliputi tiga hal pokok, yaitu sebagai berikut:

a. Permintaan pemeriksaan tentang sah atau tidaknya suatu penangkapan atau penahanan yang diajukan oleh tersangka, keluarga atau kuasanya kepada ketua pengadilan negeri dengan menyebutkan alasannya.

b. Permintaan untuk memeriksa sah atau tidaknya suatu penghentian penyidikan atau penuntutan dapat diajukan oleh penyidik atau penuntut umum, pihak ketiga yang berkepentingan kepada ketua pengadilan negeri dengan menyebutkan alasannya.

Permintaan ganti kerugian dan/atau rehabilitasi akibat tidak sahnya penangkapan atau penahanan atau akibat sahnya penghentian penyidikan atau penuntutan diajukan oleh tersangka atau pihak ketiga yang berkepentingan kepada ketua pengadilan negeri dengan menyebutkan alasannya.

\section{PENUTUP}

Salah satu perkara pengajuan pra peradilan terhadap penetapan tersangka dugaan melakukan tindak pidana korupsi adalah Putusan Nomor: 6/Pid.Pra/2020/PN.Tjk, dimana pada putusan tersebut menyatakan bahwa berdasarkan pertimbangan-pertimbangan tersebut diatas, Hakim berkesimpulan bahwa tindakan-tindakan Termohon yang menetapkan Pemohon sebagai Tersangka karena adanya penyimpangan pengeluaran anggaran Sekretariat DPRD Kabupaten Tulang Bawang Tahun Anggaran 2018-2019 telah sesuai peraturan perundang undangan, sehingga Surat Penetapan Tersangka Nomor S.Tap/03/VI/2020/ Ditreskrimsus tertanggal 23 Juni 2020 terhadap Pemohon adalah sah dan mempunyai kekuatan hukum mengikat. Memperhatikan Pasal 77 Undang-undang 
Nomor 8 Tahun 1981 tentang Hukum Acara Pidana, Putusan Mahkamah Konstitusi Nomor 21/PUU-XII/2014 tertanggal 28 April 2015 dan Peraturan Mahkamah Agung RI Nomor 4 Tahun 2016 serta peraturan perundangundangan lain yang bersangkutan serta Menolak permohonan praperadilan Pemohon untuk seluruhnya. 


\section{DAFTAR PUSTAKA}

Buku

Anang Priyanto, 2012. Hukum Acara Pidana Indonesia. Ombak. Yogyakarta.

Andi Hamzah. 2010. Hukum Acara Pidana Indonesia. Sinar Grafika. Jakarta.

H.M.A Kuffal. 2008. Penerapan KUHAP dalam Praktik Hukum, UMM Press, Malang.

M. Yahya Harahap. 2008. Pembahasan Permasalahan dan Penerapan KUHAP (Pemeriksaan Sidang Pengadilan. Banding. Kasasi dan Peninjauan Kembali). Sinar Grafika. Jakarta.

M. Yahya Harahap. 2010. Pembahasan Permasalahan dan Penerapan KUHAP Pemeriksaan Sidang Pengadilan, Banding, Kasasi dan Peninjauan Kembali. Sinar Grafika. Jakarta.

Moch. Faisal Salam,.2001. Hukum Acara Pidana Dalam Teori \& Praktek. Mandar Maju. Bandung.

Mochamad Anwar,1989, Pra peradilan, Jakarta, Ind-Hil-Co.

Nur Hidayat. 2010. Penghentian Penyidikan Oleh Penyidik Polri dan Upaya Hukumnya. Jurnal Yustitia. Vol.10. No.1.

R. Soeparmono, 2003. Pra peradilan dan Penggabungan Perkara Ganti Kerugian dalam KUHAP, Mandar Maju, Bandung.

Ratna Nurul Afiah. 1986. Pra peradilan dan Ruang Lingkupnya. Akademika Pressindo. Jakarta.

Tri Andrisman, 2010, Hukum Acara Pidana, Unila Press. Bandar Lampung. 